\title{
Synoptic climate change as a driver of late Quaternary glaciations in the mid-latitudes of the Southern Hemisphere
}

\author{
H. Rother and J. Shulmeister \\ Department of Geological Sciences, University of Canterbury, Private Bag 4800, Christchurch, New Zealand \\ Received: 23 September 2005 - Published in Clim. Past Discuss.: 1 December 2005 \\ Revised: 8 March 2006 - Accepted: 28 March 2006 - Published: 12 May 2006
}

\begin{abstract}
The relative timing of late Quaternary glacial advances in mid-latitude $\left(40-55^{\circ} \mathrm{S}\right)$ mountain belts of the Southern Hemisphere (SH) has become a critical focus in the debate on global climate teleconnections. On the basis of glacial data from New Zealand (NZ) and southern South America it has been argued that interhemispheric synchrony or asynchrony of Quaternary glacial events is due to Northern Hemisphere $(\mathrm{NH})$ forcing of $\mathrm{SH}$ climate through either the ocean or atmosphere systems. Here we present a glacial snow-mass balance model that demonstrates that large scale glaciation in the temperate and hyperhumid Southern Alps of New Zealand can be generated with moderate cooling. This is because the rapid conversion of precipitation from rainfall to snowfall drives massive ice accumulation at small thermal changes $\left(1-4^{\circ} \mathrm{C}\right)$. Our model is consistent with recent paleo-environmental reconstructions showing that glacial advances in New Zealand during the Last Glacial Maximum (LGM) and the Last Glacial Interglacial Transition (LGIT) occurred under very moderate cooling. We suggest that such moderate cooling could be generated by changes in synoptic climatology, specifically through enhanced regional flow of moist westerly air masses. Our results imply that NH climate forcing may not have been the exclusive driver of Quaternary glaciations in New Zealand and that synoptic style climate variations are a better explanation for at least some late Quaternary glacial events, in particular during the LGIT (e.g. Younger Dryas and/or Antarctic Cold Reversal).
\end{abstract}

Correspondence to: $\mathrm{H}$. Rother

(h.rother@geol.canterbury.ac.nz)

\section{Introduction}

Quaternary glacial signals from mountain belts in the midlatitude Southern Hemisphere (mlSH), in particular from locations in New Zealand and southern South America, have become important for testing models of past and present interhemispheric climate teleconnections (e.g. Broecker, 1997; Moreno, 2001). It has been argued that synchrony of past glacial advances would be indicative of direct interhemispheric climate forcing via the atmosphere (e.g. Kaplan et al., 2004; Denton et al., 1999) whereas, asynchrony has been interpreted as a climate link through the thermohaline conveyor (e.g. Lowell et al., 1995). The focus in this debate has been on the absolute dating of Quaternary mlSH glacial advances, which are used as proxies to identify the level of global correspondence between distinct Northern Hemisphere (NH) and Southern Hemisphere (SH) climate signals.

In recent years, progress in cosmogenic and luminescence dating techniques has permitted the direct dating of glacial landforms and deposits in mlSH mountain belts. Initial results from the Southern Alps of New Zealand and the southern Andes have been interpreted as demonstrating interhemispheric synchrony of LGM glacial advances and it has also been suggested that specific LGIT climate events known from the North Atlantic region (e.g. the Younger Dryas) can be directly correlated to mountain glacier advances in the mlSH (Denton and Hendy, 1994; Ivy-Ochs et al., 1999). It has further been argued that such level of correspondence is compelling for a model of direct $\mathrm{NH}$ atmospheric forcing of glaciations in the SH (Kaplan et al., 2004; Denton et al., 1999).

Despite some indications for interhemispheric synchrony of a limited number of LGM and LGIT glacial advances, the paleo-climatological interpretation of the data is not straightforward. In the case of New Zealand, numerical paleo-environmental reconstructions using speleothems and

Published by Copernicus GmbH on behalf of the European Geosciences Union. 


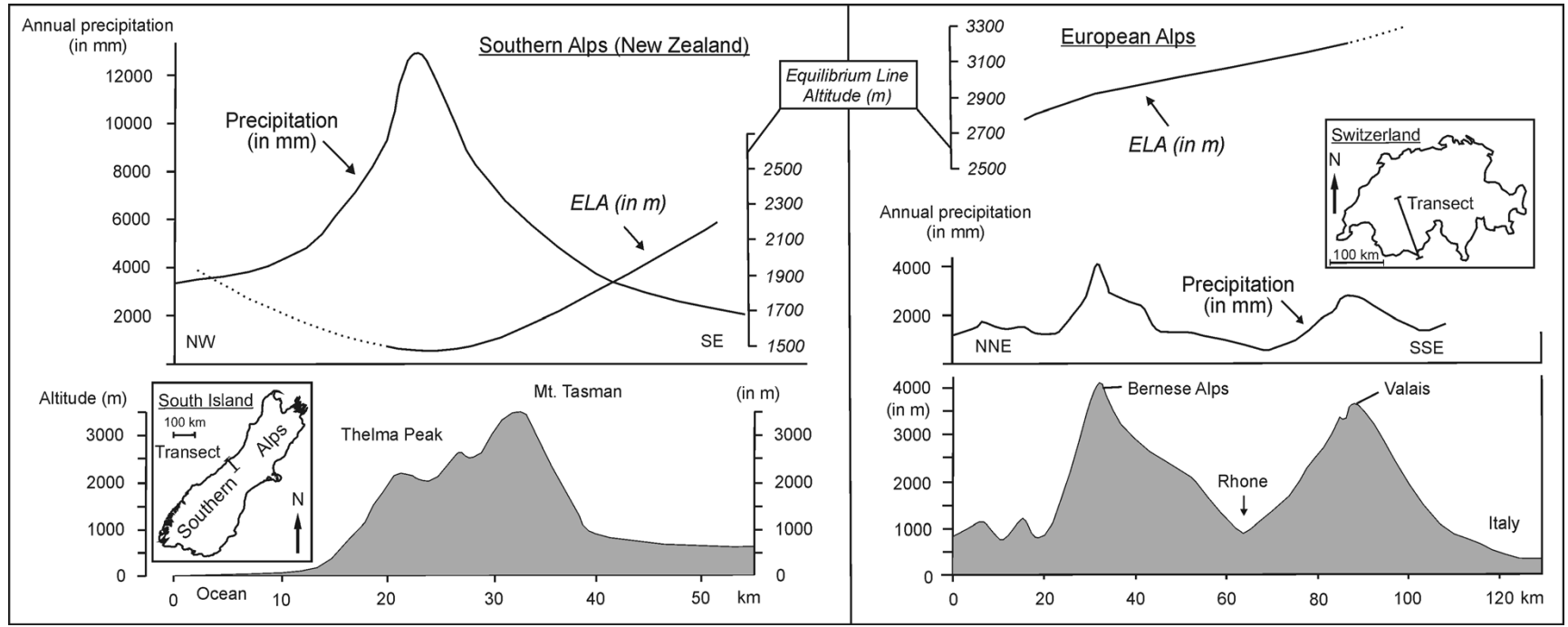

Fig. 1. Comparison of precipitation and ELA levels across the Southern Alps and European Alps (data from Mueller, 1976; Chinn and Whitehouse, 1980; Griffiths and McSaveney, 1983) plotted at equal scales (except horizontal distances) (modified from Sturman and Wanner, 2001). In New Zealand heavy orographic precipitation is concentrated in a $15-20 \mathrm{~km}$ wide sector along the alpine divide with annual totals 3-4 times greater than in the European Alps. The marked distribution of precipitation causes a strong ELA depression and very steep ELA gradients. In the European Alps, the NNW-SSE rise in ELA is mainly due to the meridional temperature increase.

fossil beetle assemblages show that LGM cooling was very moderate (Hellstrom et al., 1998) and possibly as little as 2 to $3^{\circ} \mathrm{C}$ (Marra et al., 2006). The paleo-ELA ${ }^{1}$ depression suggests a cooling in the vicinity of $4-5^{\circ} \mathrm{C}$ (Porter, 1975; Soons, 1979). These results are supported by General Circulation Model (GCM) calculations that predict a 2 to $3^{\circ} \mathrm{C}$ lower sea-surface temperature (SST) in the Tasman Sea during the LGM (Hewitt and Mitchell, 1997) while SST reconstructions from forams suggest slightly stronger cooling at $\mathrm{c}$. $4^{\circ} \mathrm{C}$ (Barrows and Juggins, 2005). In short, none of the reconstructions suggest a cooling of more than $5-7^{\circ} \mathrm{C}$ in NZ during the LGM while the lower end of the reconstructions suggest cooling similar to the modern interannual variability associated with ENSO and other oscillatory systems.

For the LGIT, at least one glacial re-advance has been demonstrated for the Southern Alps (Denton and Hendy, 1994; Ivy-Ochs et al., 1999), however, this re-advance, which was originally correlated to the Younger Dryas (YD) (Denton and Hendy, 1994), is neither universally detected in NZ's glacial records (e.g. Shulmeister et al., 2005) nor, critically, is a significant simultaneous cooling apparent from pollen or other paleoecological records (e.g. Singer et al., 1998; Turney et al., 2003). The New Zealand pollen records suggest a pause or minor reversal in the post-glacial warming only between $14.6-13.6 \mathrm{cal} .{ }^{14} \mathrm{C}$ ka (McGlone, 1995, 2004)

\footnotetext{
${ }^{1}$ The ELA separates glacial accumulation from ablation areas and represents the altitude at which the glacial mass balance is zero. Key factors influencing the position of the ELA are long term mean temperatures and precipitation.
}

while warming resumed during the following YD chronozone (12.7-11.5 ka). Despite ongoing debate about the precise timing and correlation of LGM and LGIT glacial advances in New Zealand, the broader paleoecological data appear robust, and it has been difficult to resolve the occurrence of significant glacial expansions contemporaneous with only moderate cooling. The problem has wider implications because similar confusion has characterized the LGIT debate in southern South America with various authors proposing cooling or an absence thereof during the LGIT (e.g. Moreno et al., 2001; Bennett et al., 2000).

In this paper we present a snow mass balance model from the Southern Alps of New Zealand to test the sensitivity of glacial accumulation to thermal changes. By doing so we analyse whether the emerging glacio-chronological and paleoecological records from New Zealand are in fact compatible and if minor thermal forcing is sufficient to cause full-scale glacial expansion in the Southern Alps. The question has wider relevance because under such a scenario we must consider the possibility that some Quaternary glacial advances in NZ, and by implication in parts of South America, were generated by synoptic climate variations alone, requiring little (during the LGM) or no (during the LGIT) climate forcing from the $\mathrm{NH}$.

\section{Glaciological setting: New Zealand}

New Zealand is located in the Southern Hemisphere westerly wind belt and is characterized by an oceanic climate. The 



Fig. 2. Minimum cirque floor elevations of the western/central and eastern Southern Alps. Clearly defined cirque basins were mapped along four $30 \mathrm{~km}$ wide transects as shown in the inset of $2 \mathrm{~A}$. The data indicate that steep west-east precipitation and snowline gradients persisted throughout the late Quaternary.

regional climate is profoundly affected by the NE-SW trending Southern Alps $\left(41^{\circ}-46^{\circ} \mathrm{S}\right)$ which constitute a $\sim 3 \mathrm{~km}$ high topographic barrier in the pathway of the Southern Ocean Westerlies. Due to the interception and rapid orographic forcing of west flowing moist air masses, the central Southern Alps are amongst the wettest places on the planet. Annual precipitation near the alpine divide is commonly in excess of $9000 \mathrm{~mm}$ with observed maximum values at around $16000 \mathrm{~mm}$ (Griffiths and McSaveney, 1983; Henderson and Thompson, 1999; Fig. 1). Critical for the glaciological setting is the marked cross-alpine precipitation distribution and the presence of a narrow hyperhumid sector which stretches along the full length of the Southern Alps. Virtually all of New Zealand's c. 3100 present glaciers are located in this sector (National Snow and Ice Data Center, 1999). Glaciers of perhumid environments are generally characterized as high ice turn-over systems with large positive and negative mass balances, high glacial flow velocities and relatively short climatic reaction times (Woo and Fitzharris, 1992; Benn and Evans, 1998).

Glacial Equilibrium Line Altitudes (ELAs) in the Southern Alps closely reflect the steep windward-leeward precipitation contrast which causes ELA gradients in New Zealand to be up to 20 times steeper than those reported for arctic and subarctic regions (Chinn and Whitehouse, 1980; Andrews and Miller, 1972). Despite this distinct glaciological setting,
Quaternary glacial records from the Southern Alps are often directly correlated to records from other mid-latitude mountain belts, in particular to those from the European Alps (e.g. Ivy-Ochs et al., 1999). A comparison of key glacial parameters of the two ranges (Fig. 1) shows that despite substantially greater mean elevations, the European Alps receive only a quarter to a third of the NZ precipitation values while its distribution is far more even. A direct consequence of the hyperhumidity in the central Southern Alps is a strong depression of the ELA (Chinn and Whitehouse, 1980), which is generally about $1000 \mathrm{~m}$ lower than in the European Alps (Mueller, 1976). The differences in the physical setting have important implications for mechanisms of glacial accumulation and the resulting styles of glaciations in the two mountain belts.

Because New Zealand's glaciological configuration is fundamentally related to the interaction between the Southern Alps and the Westerly wind belt, studies of regional paleocirculation patterns are critical to the reconstruction of former glacial base conditions. Evidence for enhanced ocean upwelling east of New Zealand (Fenner et al., 1992; Weaver et al., 1998) and maxima in dust flux (Thiede, 1979; Stewart and Neall, 1984; Carter et al., 1995) have generally been attributed to persistent and strong westerly flow during the LGM (e.g. Markgraf et al., 1992; Shulmeister et al., 2004). Glacio-eustatic sea level lowering increased the relative height of the Southern Alps which in turn intensified 


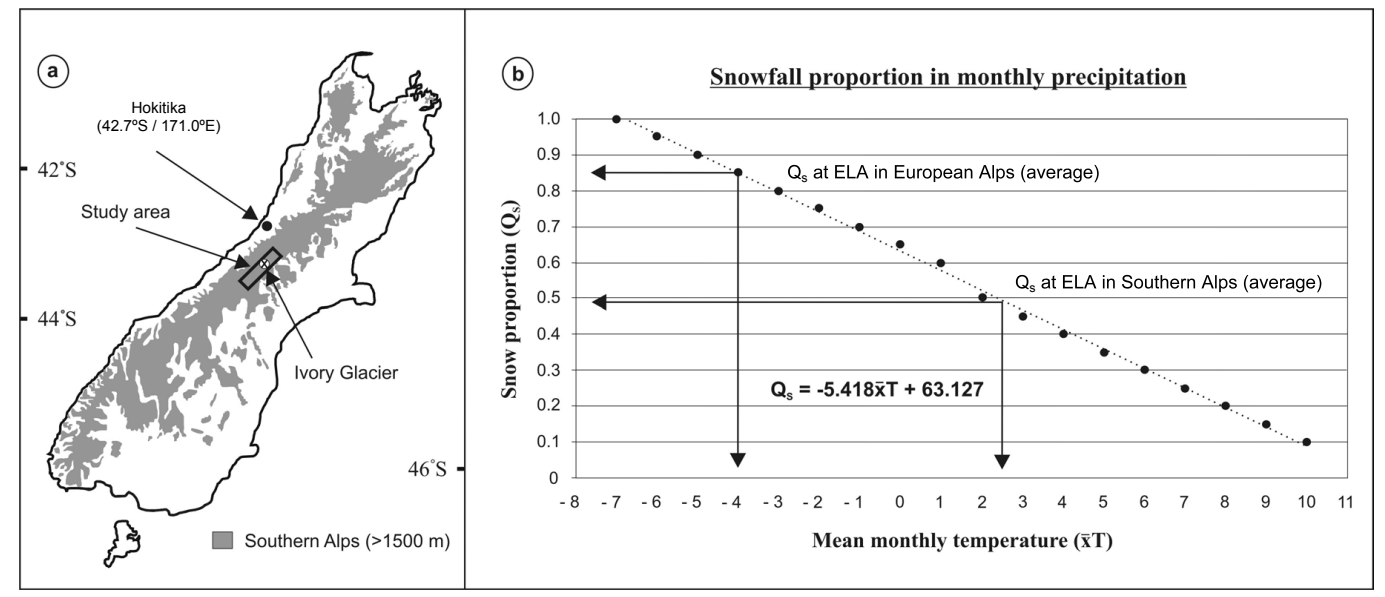

Fig. 3. Locations of study area, Hokitika climate station and Ivory Glacier in the Southern Alps (a). (b) shows the physical relationship between mean monthly temperature and the snow-rain ratio $\left(Q_{S}\right)$ as derived empirically from the Swiss Alps (Sevruk, 1992).

orographic forcing of moist westerly air masses. It is therefore probable that strong windward-leeward gradients in precipitation and ELA across the Southern Alps remained intact during Quaternary glacial periods. This is supported by reconstructed paleo-ELAs from cirque floor elevations comparing the western/central to the eastern alps (Fig. 2). Results show that despite an estimated $\sim 800 \mathrm{~m}$ ELA lowering (Porter, 1975), steep paleo-ELA gradients persisted during past glaciations.

To summarise, the combination of hyperhumidity and steep paleo-ELA gradients during Late Quaternary glaciations is responsible for a specific style of glacial accumulation in New Zealand. Firstly, very high levels of snowfall occurred in a $15-30 \mathrm{~km}$ wide sector near the alpine divide which corresponded with the area of minimum ELA. Secondly, due to rainshadow effects and because the ELA rose sharply east of the divide, alpine areas only a short distance from the divide received significantly less snowfall and only the highest peaks penetrated the annual snowline. This resulted in a glacial pattern where large scale ice accumulation was concentrated in the narrow perhumid sector of the central alps, while the contribution of all other areas to overall glacial accumulation in the Southern Alps was orders of magnitude smaller.

\section{Temperature effects on snow mass balances in the Southern Alps}

In the central Southern Alps present ELAs range between $1500 \mathrm{~m}-2100 \mathrm{~m}$ (Lamont et al., 1999). Critically, at these ELAs atmospheric temperatures remain above freezing for considerable periods of the year. This means that a significant portion of the large annual precipitation at and around ELA level falls as rain. This constitutes a substantial snow resource if climate cooling occurs as additional snow is gen- erated without any synoptic changes. By comparison, in the European Alps present ELAs are on average $1000 \mathrm{~m}$ higher $(2500 \mathrm{~m}-3500 \mathrm{~m})$ and corresponding atmospheric temperatures remain too cold for rain to form a significant portion in the annual precipitation at ELA (Fig. 3b).

To investigate temperature effects on glacial accumulation in the perhumid Southern Alps we use a snow mass balance mode ${ }^{2}$. The model calculates annual net snow accumulation for various cooling scenarios $\left(-1\right.$ to $-9^{\circ} \mathrm{C}$ in mean $\left.T\right)$ by analysing temperature related changes to the snow-rainratio, total annual precipitation and snow ablation rates. Data are calculated for the central perhumid alpine sector (Fig. 3a) with an ELA of $1600 \mathrm{~m}$ (Chinn and Whitehouse, 1980; Clare et al., 2002) and a total annual precipitation of $9000 \mathrm{~mm}$ (Griffiths and McSaveney, 1983; Henderson and Thompson, 1999). The overall topography, ELA position and the amount of annual precipitation in this area represent average condition for substantial portions in the central alps. Temperature data used in the model are derived from the nearest climate station (Hokitika, Fig. 3a) and were converted to the ELA altitude by using a standard environmental lapse rate of $6^{\circ} \mathrm{C} / \mathrm{km}$. We calculated cooling related changes to net snow accumulation at ELA $(1600 \mathrm{~m})$ where the current snow mass balance is zero. Mean temperatures were then incrementally lowered to simulate potential atmospheric cooling.

Observations on snow proportions $\left(Q_{S}\right)$ in total precipitation $\left(P_{\text {total }}\right)$ are not available for the Southern Alps but it has been shown that snow proportions correlate well to mean monthly temperatures (Lauscher, 1954; Cehak-Trock, 1958). We calculated $Q_{S}$ in $P_{\text {total }}$ using a regression function derived empirically from 32 stations in the Swiss Alps (Sevruk, 1992) (Fig. 3b). $Q_{S}$ results for the Southern Alps were then

\footnotetext{
${ }^{2}$ Full details on the model are provided in the attached data depository available under: http://www.clim-past.net/2/11/2006/ cp-2-11-2006-supplement.zip
} 

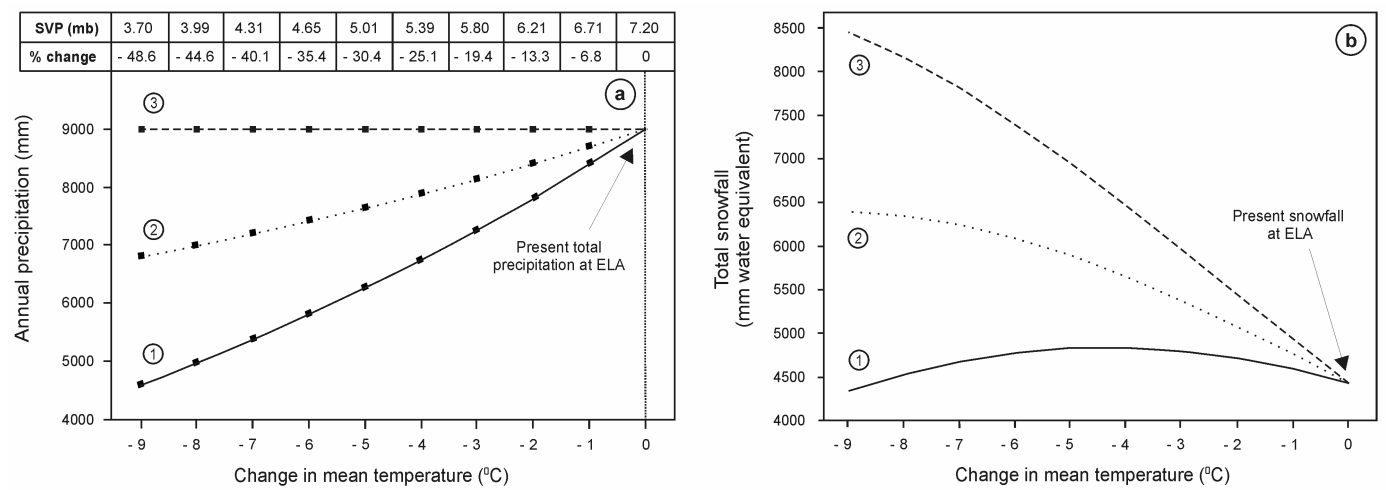

Fig. 4. The three annual precipitation scenarios (a). Scenario 1 approximates cooling related changes through variations in air saturation vapour pressure (SVP) (see table in 4a). Scenario 2 assumes half the change of scenario 1, and scenario 3 assumes no change in precipitation with cooling. Figure $4 \mathrm{~b}$ shows annual snowfall under cooling as a result of changes to the snow-rain ratio and variations in total annual precipitation. Snowfall is adjusted to the seasonal variation in precipitation.

adjusted for the seasonal variation in precipitation by applying weighted averages from the observed monthly precipitation at the nearby Ivory Glacier (Anderton and Chinn, 1978; Fig. 3a). At ELA (1600 m) mean annual temperature is $2.3^{\circ} \mathrm{C}$ with a monthly range from $-2.1^{\circ} \mathrm{C}$ (July) to $6.4^{\circ} \mathrm{C}$ (February). Results show that at this elevation $49.2 \%(4430 \mathrm{~mm}$ water equivalent) of the annual total of $9000 \mathrm{~mm}$ fall as snow while the remaining $50.8 \%(4570 \mathrm{~mm})$ fall as rain. This provides an enormous potential additional snow source. For every $1^{\circ} \mathrm{C}$ of cooling in mean monthly temperature the percentage of snow as a proportion of precipitation grows by $5.5 \%$ (Fig. 3b).

Atmospheric cooling is likely to affect the amount of total annual precipitation received by the Southern Alps. Recent studies have suggested relatively wet conditions in New Zealand associated with enhanced Westerlies during the LGM (e.g. Eden and Hammond, 2003; Shulmeister et al., 2004) and LGIT (e.g. Pepper et al., 2004), while others argue that humidity was somewhat reduced during glacial periods (e.g. Hope et al., 2004). At present no quantified paleo-data on the response of precipitation in the New Zealand region to LGM and LGIT cooling exist. In general, precipitation will respond to cooling by adjusting to changes in air mass saturation vapour pressure, evaporation and to variations in the route and velocity of atmospheric transport. In order to demonstrate the general relationships between precipitation, temperature, snow-rain ratios and snow accumulation in the New Zealand setting we use three simple precipitation scenarios to account for a range of possible precipitation values (Fig. 4a). Scenario 1 assumes a cooling related decrease in annual precipitation and approximates the non-linear reduction through temperature related variations in air mass saturation vapour pressure (SVP). In this scenario, the precipitation decrease is calculated from SVP changes which are used to approximate the moisture capacity of the air where a cooling of $-5^{\circ} \mathrm{C}$ would reduce overall humidity by $\sim 30 \%$. In sce- nario 2 , the reduction in annual precipitation is assumed to be half of that of scenario 1 and scenario 3 assumes wet conditions where precipitation totals remain at the present levels even under increasingly colder conditions. The scenarios are designed for the purpose of this model study only and do not accurately describe the actual response of precipitation to past glacial cooling in New Zealand, however the scenarios cover the generally suggested last glacial precipitation estimates.

Results in Fig. 4b show total annual snowfall for increasingly colder conditions as calculated when the precipitation scenarios are combined with the dynamic snow-rain ratio. As expected snowfall totals vary greatly depending on the modelled annual precipitation. The data generally reflect two compensating trends during cooling, firstly the continuing increase of $Q_{S}$ in $P_{\text {total }}$, and secondly a cooling related decline in $P_{\text {total }}$ (scenarios 1 and 2). Results indicate that the addition of large amounts of extra snow from the rain-snow conversion would have dramatic effects on snow mass balances in perhumid environments. Snowfall increases (scen. 2) or remains high (scen. 1) even if annual precipitation declines substantially. If conditions are wetter (scen. 3) snowfall will expand vastly as $P_{\text {total }}$ remains very high.

The projected annual snowfall total must be related to ablation for assessing net annual snow accumulation. We calculated snow ablation by using a degree day mass balance (DDMB) model in which mean daily temperatures are taken as an integrated index of the heat budget and where ablation is assumed to occur proportionally to the mean air temperature (e.g. Linsley, 1947). DDMB models have been widely tested under field conditions where they have shown to predict ablation reliably (e.g. Komarov et al., 1969; Braithwaite and Olesen, 1989; Jóhannesson et al., 1995; Braithwaite and Zhang, 2000). Calculation use the formula:

$a(z)=k T_{\text {sum }}(z)+H_{S} /, T>0 C^{\circ}$ 



Fig. 5. Impact of cooling on snow ablation at present ELA as calculated by a degree day mass balance model (a). (b) shows projected annual net snow accumulation as a result of variations in annual precipitation, snow-rain proportions and ablation under -1 to $-9^{\circ} \mathrm{C}$ cooling. Note the steep increase in snow accumulation at moderate cooling.

where ablation $(a)$ is computed for elevation $(z)$, using the sum of positive mean daily temperatures $\left(T_{\text {sum }}\right)$ at $z$. The positive degree days are multiplied with $\mathrm{k}$ representing an empirically derived degree day factor. We use a degree day factor of $4.5 \mathrm{~mm}$ day-1 deg- 1 as was derived for Franz Josef Glacier in the central Southern Alps (Anderson, 2003). $H_{S}$ is ablation from latent heat (rain on snow) which contributes $\sim 2 \%$ to annual ablation in the Southern Alps (Hay and Fitzharris, 1988). We tested the model by predicting ablation at the present ELA where annual snowfall is $4432 \mathrm{~mm}$ and no net accumulation occurs (mass balance 0 ). The model indicates $4359 \mathrm{~mm}$ of ablation, underestimating actual ablation by only $1.7 \%$. Overall results in Fig. 5a show how snow ablation decreases at ELA under intensifying cooling from $4432 \mathrm{~mm} / \mathrm{a}$ (at present temperature conditions) until it virtually stops at $-6.5^{\circ} \mathrm{C}$ cooling.

We then integrated all previously analyzed parameters (snow-rain proportions, total precipitation, snow ablation) to predict net snow accumulation in the central alps under increasingly cooler conditions. Results are shown in Fig. 5b where $0^{\circ} \mathrm{C}$ represents current climate conditions at the ELA with no net accumulation. The outcome indicates that net snow accumulation in the Southern Alps responds strongly positive to moderate cooling. Snow accumulation grows dramatically under all precipitation scenarios even when overall humidity declines substantially. A striking feature is the steep increase recorded for the early part of the cooling (1$4^{\circ} \mathrm{C}$ ), where snow accumulation grows markedly mainly due to the rapid conversion from rain to snow. A cooling of only $2-3^{\circ} \mathrm{C}$ at present ELA would result in the net annual addition of $\sim 15$ vertical meters of snow (Fig. 5b). Interestingly, the gain generally slows with more severe cooling. For precipitation scenario 1 (driven by SVP changes) the snow accumulation trend will even reverse at around $-6^{\circ} \mathrm{C}$ cooling when net annual accumulation starts to decline. The effect is caused by high snow proportions at this cooling and the effective halt of ablation after which the continuing decrease of total annual precipitation drives net accumulation down.

\section{Discussion and conclusion}

Heavy orographic precipitation in the central parts of the long $(\sim 800 \mathrm{~km})$ but narrow $(\sim 80 \mathrm{~km})$ Southern Alps results in some of the steepest recorded glacial ELA gradients on Earth. During Quaternary glaciations and associated low sea level stands, the relative height of the Southern Alps as a barrier for moist westerly air masses was further enhanced and ELA gradients were maintained or even steepened. Reconstructed paleo-ELAs (Porter, 1975; Chinn and Whitehouse, 1980) imply that ice accumulation during the LGM was concentrated in the perhumid central alps. These conditions produced extensive ice fields or possibly a narrow ice cap, which covered the $\sim 30 \mathrm{~km}$ wide hyperhumid sector near the alpine divide. From the central alpine accumulation zone valley glaciers extended on average $50-70 \mathrm{~km}$ to their LGM terminal positions.

Our snow mass balance data indicate that glacial accumulation in the Southern Alps is sensitive to small thermal changes. Moderate cooling $\left(2-4^{\circ} \mathrm{C}\right)$ is sufficient to increase snowfall dramatically and trigger large positive excursions in glacial mass balances. If this cooling is sustained under a $5000-8000 \mathrm{~mm}$ precipitation regime it is possible to generate glacial advances of the scale recorded for the LGM. The high temperature sensitivity of glacial systems in New Zealand is mainly due to extreme perhumidity and associated low ELA levels which cause present glacial accumulation areas in the Southern Alps to receive substantial amounts of rain. The rain-snow conversion would impact rapidly as present precipitation maxima occur during the cooler Autumn and Spring seasons thereby requiring only moderate further cooling to initiate full rain-snow conversion.

The model assumptions account for a cooling related decrease in total annual precipitation, which is consistent with LGM humidity estimates suggested from New Zealand pollen (McGlone, 1995). Likewise, regional paleotemperature reconstructions using speleothems and fossil beetle assemblages indicate that cooling during the LGM 
and LGIT glacial advances was only moderate (Hellstrom et al., 1998) and possibly as little as -2 to $-3^{\circ} \mathrm{C}$ (Marra et al., 2006). The benefit of our mass balance model is that it provides a mechanism that resolves the occurrence of substantial glacial advances in New Zealand contemporaneous with reconstructed drier conditions and with only moderate atmospheric cooling. We note that under a scenario where total precipitation in glacial New Zealand would noticeable increase (for example due to higher wind speeds or altered atmospheric transport pathways) glaciation in the Southern Alps could be generated with even less cooling then suggested by the present study.

For the central Southern Alps, hypsometric characteristics of areas immediately below snowline $(\sim 1400-1700)$ suggest that a moderate drop in ELA would bring extensive low angle surface areas above snowline. This factor is important because new permanent snow accumulations can only occur if slope angles are suitable. The effect is demonstrated for our study area where we calculated hypsometric integrals for a $10 \mathrm{~km}$ wide and $60 \mathrm{~km}$ long sector (S $43^{\circ} 17^{\prime} 1^{\prime \prime} / \mathrm{E} 170^{\circ} 53^{\prime} 4^{\prime \prime}$ to $\mathrm{S} 42^{\circ} 50^{\prime} 1^{\prime \prime} / \mathrm{E} 171^{\circ} 29^{\prime} 0^{\prime \prime}$ ) (Fig. 6). Results indicate that an ELA lowering of only $300 \mathrm{~m}$ would more than double the low angle surface area above snowline. In reality, the increase in suitable snow accumulation surfaces would be further enhanced by the extension of glacial tongues into the upper valleys where they raise the effective elevation of the valley floor (high-mass-balance feedback).

Moderate cooling as a driver of Quaternary glacial advances in New Zealand has several important implications. Firstly, it accounts for sedimentological peculiarities associated with glacial sequences in the Southern Alps. Commonly noted features are the enormous scale of glacio-fluvial aggradation fans, the large proportion of glacio-lacustrine deposits in ice-proximal sequences and the widespread occurrence of stratified and only weakly compacted glacial diamictons (e.g. Speight, 1942; Gage, 1965, 1985; Hart, 1996). The overall climatic implication is that conditions during deposition were clearly mild enough to provide nearly year-round availability of large volumes of melt-water.

Secondly, the low thermal forcing mechanism for glaciation in New Zealand implies that large glacial advances can be generated rapidly, and conversely, shut down rapidly since glacial conditions are sensitive to small thermal changes. This "flickering switch" feature of Quaternary glacial advances in the Southern Alps is likely to have produced a larger number of individual glacial oscillation than for example is observed in the more continental European Alps. This pattern may complicate attempts to directly correlate glacial signals from the NH to New Zealand.

Thirdly, moderate cooling as a glacial driver in New Zealand highlights the distinct possibility that regional (synoptic) climate phenomena were the principle cause for some Late Quaternary glacial events. It has been shown that modern glaciers in western New Zealand respond to synoptic circulation changes, where enhanced zonal flow

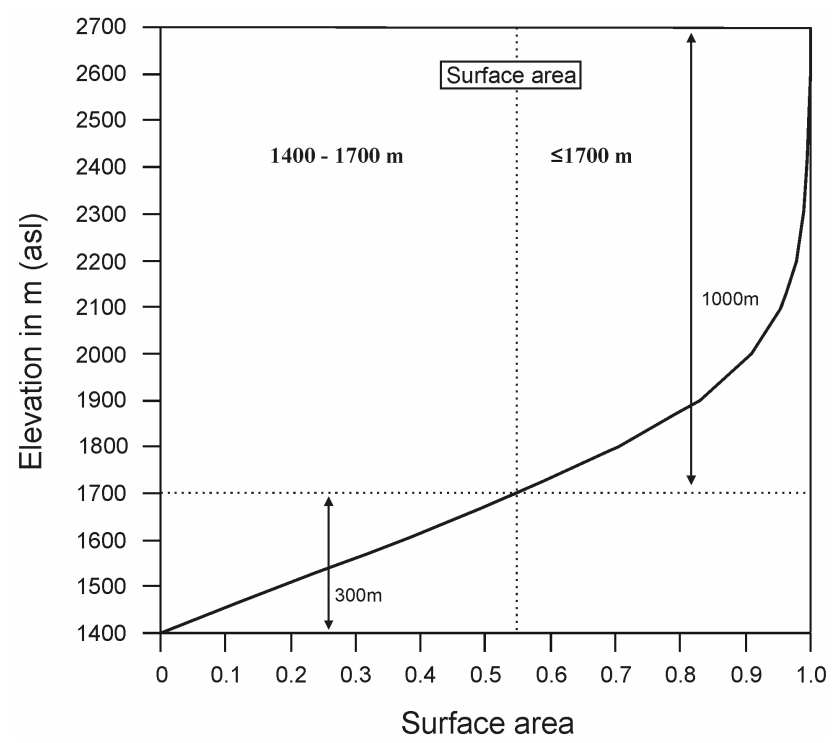

Fig. 6. DEM analysed hypsometry above $1400 \mathrm{~m}$ in the central Southern Alps showing the potential increase in low angle (less than $15^{\circ}$ ) surface areas above snowline from a $300 \mathrm{~m}$ ELA lowering $(1700 \mathrm{~m}$ to $1400 \mathrm{~m})$ The analysed alpine zone is the study area as shown in Fig. 3a. ELA lowering would increase the aerial extent of low angle surfaces by $121.5 \%$.

(westerly/south-westerly) is associated with glacial advances and stronger meridional flow is associated with retreats (Lamont et al., 1999; Hooker and Fitzharris, 1999). The reason is that strengthened westerly flow increases orographic precipitation over the mountains and reduces ablation through enhanced cloud cover, while conversely, more persistent meridional circulation is associated with reduced precipitation and clear skies that cause increased ablation. Strong westerly flow, associated with glacial advances, mirrors the impact of El Niño on New Zealand. Recent spectral analyses on varved lake sediments have highlighted the possibility of a periodically enhanced inter-annual El Niño Southern Oscillation (ENSO) signal during the LGIT over New Zealand (Pepper et al., 2004). Speleothem data from the South Island (Hellstrom et al., 1998) now supported by uranium isotope data (Robinson et al., 2004) also indicate a period of enhanced precipitation over New Zealand at around $13 \mathrm{ka}$ which may be linked to a late glacial Southern Hemisphere climate event known as the Antarctic Cold Reversal (ACR) (Jouzel et al., 2001). An ACR signal has recently been recognized in New Zealand pollen (McGlone et al., 2004) and maar lake records (Pepper et al., 2004). Alternatively, it has been suggested that a $\sim 13 \mathrm{ka}$ New Zealand climate event could represent a directly transmitted NH Younger Dryas signal (e.g. Morigi et al., 2003). Regardless of its correlation neither period is associated with marked larger scale cooling in New Zealand. Enhanced precipitation, in association with very minor cooling, would have been capable of triggering glacial re-advances in the central parts of the Southern Alps such as at Franz-Josef Glacier (Ivy-Ochs et 
al., 1999). These changes, however, would not have impacted on already deglaciated mountain systems such as the Tasman Mountains in NW Nelson (Shulmeister et al., 2005), nor on the pollen record (McGlone, 1995; Singer et al., 1998; Turney et al., 2003). A synoptic 'wet' event as the driver of the LGIT (ACR or YD) re-advance in New Zealand is therefore consistent with the available glacial record.

Synoptic climatology as the cause for late Quaternary glacial advances in hyperhumid mountain environments of the Southern Alps may provide an explanation for inconsistencies in glacial records of the SHml (Southern Alps, southern Andes), where climate signals and glacial advances have been recorded as both synchronous and asynchronous to Northern Hemisphere cooling events. The situation in South America is somewhat different in that part of the discrepancy is created by the larger geographical area covered, but at least some of the records may be reconcilable using our model. However, even if our model does not apply in all cases, the likelihood that major advances in the SHml can be explained without invoking inter-hemispheric forcing, or indeed major thermal changes, challenges current understanding of global climate linkages.

Acknowledgement. We thank C. Smart, I. Owens and P. Tonkin for comments on the manuscript and D. Richter for assistance with the hypsometric calculations. The comments by an anonymous referee helped to improve this paper. We would like to acknowledge the critical comments by B. Anderson and A. Mackintosh during the CPD online discussion. This work was supported by the University of Canterbury Research Grant No. U 6508 and through the Marsden Grant contract UoC 301 (NZ).

Edited by: A. Paul

\section{References}

Anderson, B.: The response of 'Ka Roimata o Hine Hukatere' Franz Josef Glacier to climate change, Unpublished Ph.D. thesis, University of Canterbury, Christchurch, 114pp., 2003.

Anderson, B. and Mackintosh., A.: Temperature change is the major driver of late-glacial and Holocene glacier fluctuations in New Zealand, Geology, 34(2), 121-124, 2006.

Anderton, P. W. and Chinn, T. J.: Ivory Glacier, New Zealand, an I.H.D. representative basin study, J. Glaciol., 20, 67-84, 1978.

Andrews, J. T. and Miller, G. H.: Quaternary history of the northern Cumberland Peninsula, Baffin Island, N.W.T., Canada, Arctic and Alpine Res., 4, 45-59, 1972.

Barrows, T. T. and Juggins, S.: Sea-surface temperatures around the Australasian margin and Indian Ocean during the Last Glacial Maximum, Quaternary Sci. Rev., 24, 1017-1047, 2005.

Benn, D. I. and Evans, D. J. A.: Glacier and Glaciation, London, 734p., 1998.

Bennett, K. D., Haberle, S. G., and Lumley, S. H.: The last glacialHolocene transition in southern Chile, Science, 290, 325-328, 2000

Braithwaite, R. J. and Olesen, O. B.: Calculation of glacier ablation from air temperature, West Greenland, Glacier fluctuations and climatic change, J. Oerlemans. Amsterdam, Kluwer Academic Publishers, 219-233, 1989.

Braithwaite, R. J. and Zhang, Y.: Sensitivity of mass balances of five Swiss glaciers to temperature changes assessed by tuning a degree-day model, J. Glaciol., 46, 7-14, 2000.

Broecker, W. S.: Future directions of paleoclimate research, Quaternary Sci. Rev., 16, 821-825, 1997.

Carter, L., Nelson, C. S., Neil, H .L., and Froggatt, P. C.: Correlation, dispersal, and preservation of the Kawakawa tephra and other late Quaternary tephra layers in the southwest Pacific Ocean, New Zealand J. Geol. Geophys., 38, 29-46, 1995.

Cehak-Trock, H.: Der feste Niederschlag im atlantischen Klimagebiet, Arch. Meteorologie, Geophysik, Bioklimatologie, Serie B, 8(3/4), 352-368, 1958.

Chinn, T. J. and Whitehouse, I. E.: Glacier snow line variations in the Southern Alps, New Zealand, IAHS-AISH Publ., 126, 219 228, 1980.

Clare, G. R., Fitzharris, B. B., Chinn, T. J. H., and Salinger, M. J.: Interannual variation in end-of-summer snowlines of the Southern Alps of New Zealand, and relationships with Southern Hemisphere atmospheric circulation and sea surface temperature patterns, Int. J. Climatol., 22, 107-120, 2002.

Denton, G. H. and Hendy, C. H.: Younger Dryas age advance of Franz-Josef Glacier in the Southern Alps of New Zealand, Science, 264, 1434-1437, 1994.

Denton, G. H., Heusser, C. J., Lowell, T. V., Moreno, P. I., Andersen, B. G., Heusser, L. E., Schluechter, C., and Marchant, D. R.: Interhemispheric linkage of paleoclimate during the last deglaciation, Geografiska Annaler (A), 81(2), 107-153, 1999.

Eden, D. E. and Hammond, A. P.: Dust accumulation in the New Zealand region since the last glacial maximum, Quaternary Sci. Rev., 22, 2037-2052, 2003.

Fenner, J., Carter, L., and Stewart, R.: Late Quaternary paleoclimatic and paleoceanographic change over northern Chatham Rise, New Zealand, Mar. Geol., 108, 383-404, 1992.

Gage, M.: Some characteristics of Pleistocene cold climates in New Zealand, Transact. Roy. Soc. New Zealand, 3, 11-21, 1965.

Griffiths, G. A. and McSaveney, M. J.: Distribution of mean annual precipitation across some steepland regions of New Zealand, New Zealand J. Sci., 26, 197-209, 1983.

Hart, J. K.: Proglacial glaciotectonic deformation associated with glaciolacustrine sedimentation, Lake Pukaki, New Zealand, J. Quaternary Sci., 11(2), 149-160, 1996.

Hay, J. E. and Fitzharris, B. B.: The synoptic climatology of ablation on a New Zealand Glacier, J. Climatol., 8, 201-215, 1988.

Hellstrom, J., McCulloch, M., and Stone, J.: A detailed 31 000-year record of climate and vegetation change, from the isotope geochemistry of two New Zealand speleothems, Quaternary Res., 50, 167-178, 1998.

Henderson, R. D. and Thompson, S. M.: Extreme rainfalls in the Southern Alps of New Zealand, J. Hydrol. (N.Z.), 38(2), 309330, 1999.

Hewitt, C. D. and Mitchell, J. F. B.: Radiative forcing and response of a GCM to ice age boundary conditions: cloud feedback and climate sensitivity, Climate Dyn., 13, 821-834, 1997.

Hooker, B. L. and Fitzharris, B. B.: The correlation between climatic parameters and the retreat and advance of Franz Josef Glacier, New Zealand, Global Planet. Change, 22, 39-48, 1999.

Hope, G., Kershaw, A. P., Kaars, S. v. d., Xiangjun, S., Liew, P.- 
M., Heusser, L. E., Takahara, H., McGlone, M., Miyoshi, N., and Moss, P. T.: History of vegetation and habitat change in the Austral-Asian region, Quaternary Int., 118-119, 103-126, 2004.

Ivy-Ochs, S., Schluechter, C., Kubik, P. W., and Denton, G. H.: Moraine exposure dates imply synchronous Younger Dryas glacier advances in the European Alps and in the Southern Alps of New Zealand, Geografiska Annaler, 81A, 313-323, 1999.

Johannesson, T., Sigurdsson, O., Laumann, T., and Kennett, M.: Degree-day glacier mass-balance modelling with applications to glaciers in Iceland, Norway and Greenland, J. Glaciol., 41(138), 345-358, 1995.

Jouzel, J., Masson, V., Cattani, O., Falourd, S., Stievenard, M., Stenni, B., Longinelli, A., Johnsen, S. J., Steffenssen, J. P., Petit, J. R., Schwander, J., Souchez, R., Barkov, N. I.: A new 27 ky high resolution East Antarctic climate record, Geophys. Res. Lett., 28, 3199-3202, 2001.

Kaplan, M. R., Ackert Jr., R. P., Singer, B. S., Douglass, D. C., Kurz, M. D.: Cosmogenic nuclide chronology of millennialscale glacial advances during O-isotope stage 2 in Patagonia, Geol. Soc. Amer. Bull., 116, 308-321, 2004.

Komarov, V. P., Makarova, T. T., and Sinegub, E. S.: The estimation of snowmelt runoff hydrograph of small plain rivers using snowmelt data, Transactions of the Hydro-meteorological Centre of the USSR, N37, 3-36, 1969.

Lamont, G. N., Chinn, T. J., and Fitzharris, B. B.: Slopes of glacier ELAs in the Southern Alps of New Zealand in relation to atmospheric circulation patterns, Global Planet. Change, 22, 209-219, 1999.

Lauscher, F.: Klimatologische Probleme des festen Niederschlages, Arch. Meteorologie, Geophysik, Bioklimatologie, Serie B, 6(1/2), 60-65, 1954.

Linsley, R. K., Kohler, M. A., and Paulhus, I. L.: Applied Hydrology, New York, McGraw Hill, 432p., 1947.

Lowell, T. V., Heusser, C. J., Andersen, B. G., Moreno, P. I., Hauser, A., Heusser, L. E., Schluechter, C., Marchant, D. R., and Denton, G. H.: Interhemispheric correlation of Late Pleistocene glacial events, Science, 269, 1541-1549, 1995.

Markgraf, V., Dodson, J. R., Kershaw, A. P., McGlone, M. S., and Nicholls, N.: Evolution of late Pleistocene and Holocene climates in the circum-South Pacific land areas, Climate Dyn., 6, 193-211, 1992.

Marra, M. J., Shulmeister, J., and Smith, E.: Reconstructing temperature during the Last Glacial Maximum from Lyndon Stream, South Island, New Zealand using beetle fossils and maximum likelihood envelopes, Quaternary Sci. Rev., accepted, 2006.

McGlone, M. S.: Late-glacial landscape and vegetation change and the Younger Dryas climatic oscillation in New Zealand, Quaternary Sci. Rev., 14, 867-881, 1995.

McGlone, M. S., Turney, C. S. M., Wilmshurst, J. M.: Late-glacial and Holocene vegetation and climatic history of the Cass Basin, central South Island, New Zealand, Quaternary Res., 62(3), 267279, 2004

Moreno, P. I., Jacobson, G. L., Lowell, T. V., and Denton, G. H.: Interhemispheric climate links revealed by a late-glacial cooling episode in southern Chile, Nature, 409, 804-808, 2001.

Morigi, C., Capotondi, L., Giglio, F., Langone, L., Brilli, M., Turi, B., and Ravaioli, M.: A possible record of the Younger Dryas event in deep-sea sediments of the Southern Ocean (Pacific sector), Paleogeography, Paleoclimatology, Paleoecology, 198(1-2),
265-278, 2003.

Mueller, F., Caflisch, T., and Mueller, G.: Firn und Eis der Schweizer Alpen, Geographisches Institut, ETH Zuerich, Publ. No. 57, 293p., 1976.

National Snow and Ice Data Center: World Glacier Inventory, World Glacier Monitoring Service and National Snow and Ice Data Center/World Data Center for Glaciology. Boulder, CO, 1999, updated 2003.

Pepper, A. C., Shulmeister, J., Nobes, D. C., and Augustinus, P. A.: Possible ENSO signals prior to the Last Glacial Maximum, during the last deglaciation and the early Holocene, from New Zealand, Geophys. Res. Lett., 31, L15206, doi: 10.1029/2004GL020236, 2004.

Porter, S. C.: Equilibrium-line altitudes of late Quaternary glaciers in the Southern Alps, New Zealand, Quaternary Res., 5, 27-47, 1975.

Robinson, L. F., Henderson, G. M., Hall, L., and Matthew, I.: Climate control of riverine and seawater uranium-isotope ratios, Science, 305, 851-854, 2004.

Sevruk, B. (Ed.): Snow cover measurements and aerial assessment of precipitation and soil moisture, World Meteorological Organization, Geneva, Operational Hydrological Report No. 35, WMONo. 749, 283p., pg. 129, 1992.

Shulmeister, J., Goodwin, I., Renwick, J., Harle, K., Armand, L., McGlone, M. S., Cook, E., Dodson, J., Hesse, P. P., Mayewski, P., and Curran, M.: The southern hemisphere westerlies in the Australasian sector over the last glacial cycle: a synthesis, Quaternary Int., 118-119, 23-53, 2004.

Shulmeister, J., Fink, D., and Augustinus, P.: A cosmogenic nuclide chronology of the last glacial transition in North-West Nelson, New Zealand - new insights in Southern Hemisphere climate forcing during the last deglaciation, Earth Planet. Sci. Lett., 233, 455-466, 2005.

Singer, C., Shulmeister, J., and McLea, B.: Evidence against a significant Younger Dryas cooling event in New Zealand, Science, 281, 812-814, 1998.

Speight, R.: A detail of the Pukaki moraine, Transactions and Proceedings of the Royal Society of New Zealand, 72(2), 148-157, 1942.

Stewart, R. B. and Neall, V. E.: Chronology of palaeoclimatic change at the end of the last glaciation, Nature, 311, 47-48, 1984.

Sturman, A. and Wanner, H. A comparative review of the weather and climate of the Southern Alps of New Zealand and the European Alps, Mountain Res. Dev., 21, 359-369, 2001.

Suggate, R. P.: Late Pleistocene and Quaternary glaciations of New Zealand, Quaternary Sci. Rev., 9, 175-197, 1990.

Thiede, J.: Wind regimes over the late Quaternary southwest Pacific Ocean, Geology, 7, 259-262, 1979.

Turney, C. S. M., McGlone, M. S., and Wilmhurst, J. M.: Asynchronous climate change between New Zealand and the North Atlantic during the last deglaciation, Geology, 31(3), 223-226, 2003.

Weaver, P. P. E., Carter, L., and Neil, H. L.: Response of surface water masses and circulation to late Quaternary climate change, east of New Zealand, Paleoceanography, 13, 70-83, 1998.

Woo, M. and Fitzharris, B. B.: Reconstruction of mass balance variations for Franz Josef Glacier, New Zealand, 1913-1989, Arctic Alpine Res., 24(4), 281-290, 1992. 